\title{
Quiste hidatídico renal
}

\author{
Ballesteros Sampol JJ \\ Servicio de Urología. Hospital Nuestra Señora de la Esperanza. Barcelona.
}

Actas Urol Esp. 2006;30(9):967

\section{$\mathrm{L}$} a localización renal del quiste hidatídico sólo se presenta en el 2\%-3\% de todas las hidatidosis. Es, pues, afección poco frecuente y con tendencia a disminuir en los países desarrollados aunque pueden existir zonas más o menos endémicas en las que no ha sido posible la erradicación como en nuestra cuenta del Ebro donde la incidencia epidemiológica alcanza una 10,6/100.000 h.

Nuestra experiencia se limita a 2 casos vividos en la década de los 80. Exponemos las imágenes

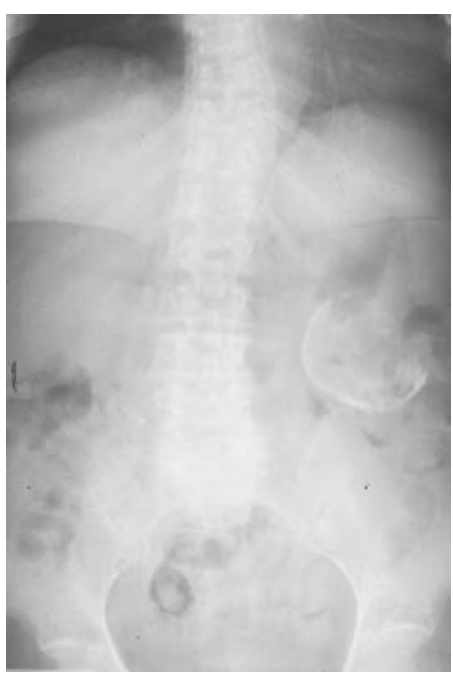

FIGURA 1. Radio simple de abdomen con imagen quistica calcificada.

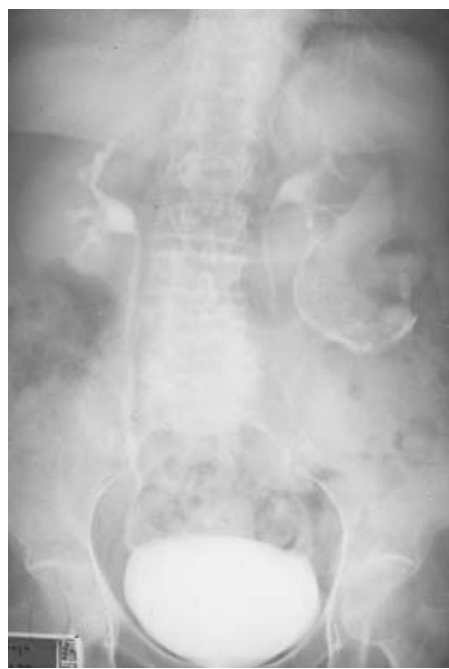

FIGURA 2. U.I.V. El quis te ocupa el hemirriñón inferior del RI. de su diagnóstico radiológico por UIV (Figs. 1 y 2), la pieza operatoria (celdectomía renal) (Fig. 3) y el característico aspecto al corte con la cavidad quística y las típicas vesículas (Fig. 4).

Dr. J.J. Ballesteros Sampol

Bori i Fontestá, $43-8^{\circ} 2^{\text {a }}$

08017 Barcelona

E-mail: jballesteros@imas.imim.es

(Trabajo recib ido el 12 de diciembre de 2005)

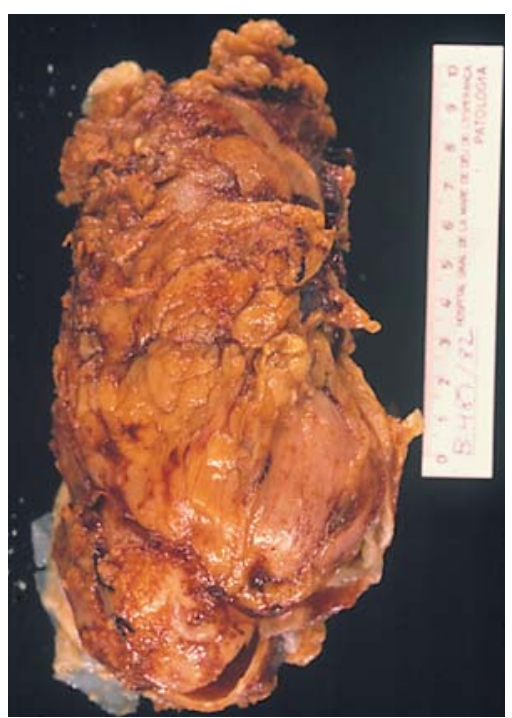

FIGURA 3. Pieza de "celdectomia" renal como si se tratara de un tumor renal.

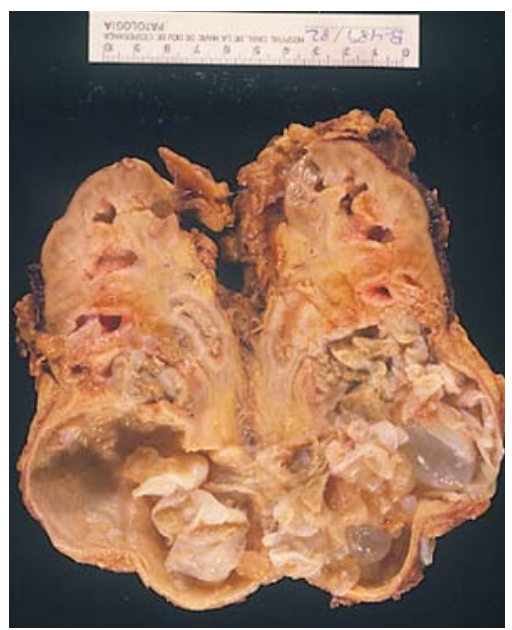

FIGURA 4. La misma pieza abierta con la cavidad quistica repleta de vesiculas. 